\title{
Unravelling Genetic Factors Underlying Corticobasal Syndrome: A Systematic Review
}

\author{
Federica Arienti ${ }^{1}{ }^{\circledR}$, Giulia Lazzeri ${ }^{1}$, Maria Vizziello ${ }^{1}$, Edoardo Monfrini ${ }^{1}{ }^{\circledR}$, Nereo Bresolin ${ }^{2}$, \\ Maria Cristina Saetti ${ }^{1}$, Marina Picillo ${ }^{3}$, Giulia Franco ${ }^{2}$ and Alessio Di Fonzo ${ }^{2, *(D)}$ \\ 1 Dino Ferrari Center, Department of Pathophysiology and Transplantation, Neuroscience Section, \\ University of Milan, 20122 Milan, Italy; federica.arienti@unimi.it (F.A.); giulia.lazzeri@outlook.com (G.L.); \\ maria.vizziello@gmail.com (M.V.); edoardo.monfrini@unimi.it (E.M.); cristina.saetti@unimi.it (M.C.S.) \\ 2 Foundation IRCCS Ca' Granda Ospedale Maggiore Policlinico, Neurology Unit, 20122 Milan, Italy; \\ nereo.bresolin@unimi.it (N.B.); giulia.franco@policlinico.mi.it (G.F.) \\ 3 Center for Neurodegenerative Diseases, Department of Medicine, Surgery and Dentistry, \\ Neuroscience Section, University of Salerno, 84084 Salerno, Italy; mpicillo@unisa.it \\ * Correspondence: alessio.difonzo@policlinico.mi.it; Tel.: +39-025-503-3807
}

Citation: Arienti, F.; Lazzeri, G.; Vizziello, M.; Monfrini, E.; Bresolin, N.; Saetti, M.C.; Picillo, M.; Franco, G.; Di Fonzo, A. Unravelling Genetic Factors Underlying Corticobasal Syndrome: A Systematic Review. Cells 2021, 10, 171. https://doi.org/ 10.3390/cells10010171

Received: 25 November 2020

Accepted: 12 January 2021

Published: 15 January 202

Publisher's Note: MDPI stays neutral with regard to jurisdictional claims in published maps and institutional affiliations.

Copyright: (c) 2021 by the authors. Licensee MDPI, Basel, Switzerland. This article is an open access article distributed under the terms and conditions of the Creative Commons Attribution (CC BY) license (https:// creativecommons.org/licenses/by/ $4.0 /)$.

\begin{abstract}
Corticobasal syndrome (CBS) is an atypical parkinsonian presentation characterized by heterogeneous clinical features and different underlying neuropathology. Most CBS cases are sporadic; nevertheless, reports of families and isolated individuals with genetically determined CBS have been reported. In this systematic review, we analyze the demographical, clinical, radiological, and anatomopathological features of genetically confirmed cases of CBS. A systematic search was performed using the PubMed, EMBASE, and Cochrane Library databases, included all publications in English from 1 January 1999 through 1 August 2020. We found forty publications with fifty-eight eligible cases. A second search for publications dealing with genetic risk factors for CBS led to the review of eight additional articles. GRN was the most common gene involved in CBS, representing 28 out of 58 cases, followed by MAPT, C9ORF72, and PRNP. A set of symptoms was shown to be significantly more common in GRN-CBS patients, including visuospatial impairment, behavioral changes, aphasia, and language alterations. In addition, specific demographical, clinical, biochemical, and radiological features may suggest mutations in other genes. We suggest a diagnostic algorithm to help in identifying potential genetic cases of CBS in order to improve the diagnostic accuracy and to better understand the still poorly defined underlying pathogenetic process.
\end{abstract}

Keywords: corticobasal syndrome; corticobasal degeneration; CBS; atypical parkinsonism; genetics

\section{Introduction}

Corticobasal syndrome (CBS) is a rare neurological disorder characterized by a combination of asymmetric akinetic-rigid parkinsonism, fixed dystonic postures, pyramidal signs, and cognitive deficits, such as behavioral changes, speech and language alterations, apraxia, visuospatial impairment, and other cortical signs, including alien-limb phenomena, myoclonus, and cortical sensory loss [1].

Typically, levodopa responsiveness is limited or absent. The clinical features correlate with neuroimaging evidence of asymmetric atrophy and hypometabolism, particularly in the striatum and parietal lobes [2]. CBS has a reported prevalence of 4.9 to 7.3 cases per 100,000 individuals [3]; symptoms usually appear between the fifth and the seventh decade of life [4], and death occurs within 6 or 7 years after the symptoms' onset $[4,5]$.

Different diagnostic criteria for CBS have been proposed over time, including those advanced by Lang and Bergeron (Toronto) [6], Boeve et al. (Mayo clinic) [7], and Bak and Hodges (Cambridge) [8], as well as the latest by Armstrong et al. in 2013 [9]. Despite extensive efforts in developing more specific diagnostic criteria, the clinical diagnosis of CBS does not always match with neuropathological evidence of corticobasal degeneration 
(CBD) [10], which is pathologically classified as four-repeat (4R)-tauopathy. In fact, CBD is confirmed in only $54 \%$ of clinically diagnosed CBS cases, and the rest show patterns typical of other neurodegenerative disorders, such as progressive Alzheimer's disease (AD) or supranuclear palsy (PSP) [11]. Conversely, since CBS is a pure clinical entity and not a neuropathological one, it is appropriate to clinically diagnose it in cases with mutations in genes known to be associated with neurodegenerative disorders other than CBD.

CBS is generally recognized as a sporadic disorder, although rare familial and isolated genetic cases have been reported. When genetically determined, CBS has been mainly described in association with mutations in the genes encoding progranulin (GRN) [12] or microtubule-associated protein tau (MAPT) [12].

The purpose of this paper is to review relevant publications describing cases of genetically determined CBS and to identify distinctive clinical features that may suggest the most likely associated genetic cause.

\section{Materials and Methods}

\subsection{Literature Search}

A systematic review of the literature was performed according to the PRISMA guidelines (Preferred Reporting Items for Systematic Reviews and Meta-Analyses). The search was performed using the PubMed, EMBASE, and Cochrane Library databases and included all publications in English from 1 January 1999 through 1 August 2020.

The following search terms were applied: corticobasal syndrome, corticobasal degeneration, genetic parkinsonism, corticobasal syndrome AND GRN, corticobasal syndrome AND MAPT, corticobasal syndrome AND C9ORF72, and corticobasal syndrome AND PRNP.

We performed a second search on genetic risk factors for CBS using as search terms: genetic risk factors for corticobasal syndrome; genome-wide association study AND corticobasal syndrome; MAPT H1c haplotype AND corticobasal syndrome; $\mathrm{H} 1 / \mathrm{H} 1$ genotype and corticobasal syndrome; $M O B P$ AND corticobasal syndrome.

\subsection{Study Selection and Data Extraction}

We included all articles and case reports with a full English text available. Regarding patients' eligibility, we applied the following inclusion criteria: (1a) clinical diagnosis of possible or probable corticobasal syndrome according to the Armstrong criteria for articles published after 29 January 2013; (1b) clinical diagnosis of corticobasal syndrome according to the Cambridge, Toronto, or Mayo Clinic criteria for articles published before 29 January 2013; (2) positive genetic test results obtained through either Sanger sequencing or Next-Generation Sequencing (exome sequencing or gene panels).

The following exclusion criteria were applied: (1) The clinical description did not fit diagnostic criteria for CBS; (2) the study lacked reliable genetic testing; (3) the original text was unavailable, or the reported information was insufficient; (4) the reported case was presented in a more comprehensive study already considered in the review.

The data extracted from each article included demographic information (age at symptom onset, age at death, and gender), clinical features (both motor and neuropsychological), genetic analysis, and family history of neurological diseases; radiological features and blood tests were recorded when available.

\subsection{Statistical Analysis}

Statistical analysis of associations between demographic, clinical, familial, or radiological characteristics and each specific mutation was performed using IBM SPSS (version 20). Continuous data were compared using two-tailed t-tests. Comparison of categorical data was performed by means of Pearson's X2 test (or Fisher's exact test, if appropriate). The threshold for statistical significance was $p<0.05$. 


\section{Results}

We identified 40 publications fulfilling the inclusion criteria and collected information on 58 cases. The demographic data are summarized in Table 1. In order to explore possible genetic risk factors linked to CBS, we also reviewed eight publications that mainly dealt with the MAPT H1c haplotype and MOBP (myelin-associated oligodendrocyte basic protein).

Table 1. Demographic information of genetic corticobasal syndrome (CBS) cases included in the analysis. * indicates that values were taken only where available.

\begin{tabular}{|c|c|c|c|c|c|}
\hline & $\begin{array}{l}\text { Number of Cases } \\
\text { (\% of Total Cases) }\end{array}$ & $\begin{array}{c}\text { Mean Age of } \\
\text { Onset * (Years) }\end{array}$ & $\begin{array}{c}\text { Mean Age at } \\
\text { Death * (Years) }\end{array}$ & Male * & Female * \\
\hline GRN & $28(48 \%)$ & 58.08 & 63.57 & 10 & 7 \\
\hline$M A P T$ & $9(16 \%)$ & 48.22 & 56.33 & 4 & 5 \\
\hline C9ORF72 & $6(10 \%)$ & 50.17 & NA & 2 & 4 \\
\hline PRNP & $4(7 \%)$ & 58.75 & 60.5 & 1 & 3 \\
\hline$G B A$ & $3(5 \%)$ & 62.6 & NA & 1 & 2 \\
\hline MRS2/ZHX2 & $2(3 \%)$ & 71 & 74 & 1 & 1 \\
\hline PSEN-1 & $1(<2 \%)$ & 48 & 51 & 1 & 0 \\
\hline$A P P$ & $1(<2 \%)$ & 49 & NA & 0 & 1 \\
\hline$T D P-43$ & $1(<2 \%)$ & 72 & NA & 1 & 0 \\
\hline CHMP2B & $1(<2 \%)$ & 71 & NA & 0 & 1 \\
\hline LRRK2 & $1(<2 \%)$ & 52 & NA & 0 & 1 \\
\hline$C Y P 27 A 1$ & $1(<2 \%)$ & 47 & NA & 1 & 0 \\
\hline Total & 58 & $\begin{array}{c}56.2 \\
(\mathrm{SD} 10.45)\end{array}$ & $\begin{array}{c}61.31 \\
(\mathrm{SD} 9.85)\end{array}$ & 22 & 25 \\
\hline
\end{tabular}

GRN was the most common gene involved, with 28 cases (48\%) from 23 families, followed by MAPT (16\%), C9ORF72 (10\%), and PRNP (7\%) (Table 1).

As many as 55 patients had a clearly recorded age at onset, and for 16 of them, the age at death was also available; however, gender was only indicated for 47 patients.

Considering the study patient population as a whole, the most frequently reported symptoms / signs were asymmetric akinetic-rigid motor syndrome (97\%), limb or orobuccal apraxia (71\%), cognitive impairment (71\%), language difficulties (52\%), frontal lobe syndrome/executive impairment (52\%), behavioral changes $(45 \%)$, and dystonia (41\%).

In 24 cases $(41.4 \%)$, the left side was the most affected, whereas 13 patients $(22.4 \%)$ reported symptoms mainly on the right side; for the remaining 21 cases $(36.2 \%)$, it was either not possible to define a predominantly affected side or the data were unavailable.

In $70 \%$ of the cases, a positive family history was reported for one of the following neurological diseases: CBS, Parkinson's disease (PD), frontotemporal dementia (FTD), or non-specific dementia.

\subsection{CBS Caused by a Single-Gene Mutation}

\subsubsection{GRN Mutations in CBS}

The GRN gene (chr17q21.32) consists of 12 coding exons and one non-coding exon. It encodes progranulin, a secreted glycoprotein that is proteolytically cleaved to form granulin (GRN) peptides [13].

Granulins are involved in various cellular processes, such as inflammation, lysosomal function, cell cycle, and tissue repair [14], acting as tumor progression factors [15]. They also modulate the turnover of several proteins, including TAR DNA-binding protein 43 (TDP-43) [16]. 
In the central nervous system, GRN carries out a neurotrophic activity and is highly expressed in the granule cells of the hippocampus and in the Purkinje cells of the cerebellum [17].

Most pathogenic alterations in GRN gene are either frameshift or nonsense mutations causing premature termination of the coding sequence and degradation of the mutant RNA by nonsense-mediated decay [18]. However, point mutations disrupting the structure of the protein are also strongly suspected to be pathogenic [19]. Loss-of-function mutations in the GRN gene cause haploid insufficiency of progranulin, whose plasma levels decrease as a consequence $[20,21]$.

Autosomal dominant GRN mutations are a major cause of FTD [22] with ubiquitin and TDP-43-immunoreactive and tau-negative neuronal inclusions [23], but are also associated with other clinical phenotypes [24,25], such PSP and CBS [26,27]. Consequently, the clinical and pathological overlap between FTD and other parkinsonian disorders has led to the concept of a tauopathies spectrum. Moreover, homozygous GRN mutations have also been reported in cases of neuronal ceroid lipofuscinoses type 11 [28,29].

In the present review of published CBS cases, GRN turned out to be the most common causative gene, occurring in 48\% of CBS cases. All GRN mutations were either insertions or deletions, causing frameshift, except for one missense mutation (GRN A199V) that was described as possibly pathogenetic [30].

Positive family history for neurologic disorders was present in $61 \%$ of cases, of which $50 \%$ showed a similar CBS phenotype [31]; in 32\% of familial cases, a diagnosis of FTD in at least one other member of the family was reported.

The mean age at onset in GRN mutation carriers was 58.0 years (range: $43-70$ years), which is similar to that for sporadic CBS.

A significant association was found between the presence of GRN mutations and specific clinical manifestations shared with FTD, including visuospatial impairment, behavioral changes, aphasia, and language alterations (Table 2). Indeed, several articles reported language dysfunction as a presenting symptom in GRN carriers [32,33]. Therefore, GRN mutations seem to predispose to a neurocognitive profile that later evolves into two possible phenotypes-FTD or CBS.

The frequency of core features typical of sporadic CBS, such as asymmetrical akinetic parkinsonism, apraxia, myoclonus, pyramidal signs, cognitive impairment, cortical sensory loss, frontal lobe syndrome, and alien-limb phenomenon, was not significantly different between GRN and non-GRN subgroups (Table 2).

Concerning the MRI data, 14 GRN carriers showed asymmetrical cortical atrophy contralateral to the most involved clinical side, mainly involving the fronto-temporo-parietal cortex [34-36], while only one case exhibited symmetrical diffuse cortical atrophy [37]. Despite the lack of imaging data for 13 GRN patients, these observations are concordant with those of previous studies, demonstrating that GRN mutations are associated with widespread and asymmetric atrophy that concerns the frontal, temporal, and parietal lobes [38,39].

The neuropathologic examination was available for seven subjects only [40,41]; all of them showed TDP-43 and ubiquitin-positive, tau-negative inclusions that were most prominent in the frontal and parietal cortices and, to a lesser extent, in the temporal cortex, hippocampus, and basal ganglia, which is compatible with the FTLD-U pattern [42]. In three cases, the presence of cytoplasmatic and intranuclear inclusions predominant in the second cortical layer was reported; these characteristics are typically associated with GRN mutation and correspond to FTLD-TDP pathology type 3 according to Sampathu et al. [43] or to type 1 in the classification proposed by Mackenzie et al. [44]. 
Table 2. Comparison between GRN and MAPT/C9ORF72 carriers. Statistically significant results are in bold; the threshold for statistical significance was $p<0.05$.

\begin{tabular}{|c|c|c|c|}
\hline & $G R N$ & MAPT/C9ORF72 & $p$ Value \\
\hline Number of patients & 28 & 15 & - \\
\hline $\begin{array}{c}\text { Gender, male } \\
\text { (GRN 17; MAPT 9; C9ORF72 6) }\end{array}$ & $58.8 \%(10)$ & $40.0 \%(6)$ & 0.288 \\
\hline $\begin{array}{c}\text { Age at disease onset, years } \\
\text { (GRN 25; MAPT 9; C9ORF72 6) }\end{array}$ & $58.1 \pm 8.1$ & $49.0 \pm 11.2$ & 0.005 \\
\hline $\begin{array}{l}\text { Asymmetric akinetic-rigid } \\
\text { syndrome } \\
(\text { GRN 28; MAPT 9; C9ORF72 6) }\end{array}$ & $96.4 \%(27)$ & $100.0 \%(15)$ & 0.999 \\
\hline $\begin{array}{c}\text { Apraxia } \\
(G R N \text { 24; MAPT 9; C9ORF72 6) }\end{array}$ & $75.0 \%(18)$ & $60.0 \%(9)$ & 0.323 \\
\hline $\begin{array}{c}\text { Gait dysfunction } \\
\text { (GRN 28; MAPT 9; C9ORF72 6) }\end{array}$ & $3.6 \%(1)$ & $66.7 \%(10)$ & $<0.001$ \\
\hline $\begin{array}{c}\text { Tremor } \\
(G R N \text { 24; MAPT 9; C9ORF72 6) }\end{array}$ & $4.2 \%(1)$ & $33.3 \%(5)$ & 0.024 \\
\hline $\begin{array}{c}\text { Dystonia } \\
\text { (GRN 24; MAPT 9; C9ORF72 6) }\end{array}$ & $20.8 \%(5)$ & $60.0 \%(9)$ & 0.013 \\
\hline $\begin{array}{c}\text { Myoclonus } \\
\text { (GRN 24; MAPT 9; C9ORF72 6) }\end{array}$ & $16.7 \%(4)$ & $13.3 \%(2)$ & 0.999 \\
\hline $\begin{array}{c}\text { Pyramidal signs } \\
\text { (GRN 24; MAPT 9; C9ORF72 6) }\end{array}$ & $8.3 \%(2)$ & $26.7 \%(4)$ & 0.180 \\
\hline $\begin{array}{c}\text { Oculomotor dysfunction } \\
\text { (GRN 23; MAPT 9; C9ORF72 6) }\end{array}$ & $4.3 \%(1)$ & $33.3 \%(5)$ & 0.027 \\
\hline $\begin{array}{c}\text { Bulbar involvement } \\
(\text { GRN 28; MAPT 9; C9ORF72 6) }\end{array}$ & $10.7 \%(3)$ & $53.3 \%(8)$ & 0.004 \\
\hline $\begin{array}{l}\text { Aphasia/language impairment } \\
\text { (GRN 24; MAPT 9; C9ORF72 6) }\end{array}$ & $70.8 \%(17)$ & $33.3 \%(5)$ & 0.022 \\
\hline $\begin{array}{c}\text { Visuospatial impairment } \\
\text { (GRN 20; MAPT 9; C9ORF72 6) }\end{array}$ & $50.0 \%(10)$ & $0 \%(0)$ & 0.002 \\
\hline $\begin{array}{c}\text { Cognitive impairment } \\
\text { (GRN 23; MAPT 9; C9ORF72 6) }\end{array}$ & $82.6 \%(19)$ & $66.7 \%(10)$ & 0.436 \\
\hline $\begin{array}{c}\text { Behavioural changes } \\
\text { (GRN 24; MAPT 9; C9ORF72 6) }\end{array}$ & $66.7 \%(16)$ & $20.0 \%(3)$ & 0.008 \\
\hline $\begin{array}{c}\text { Frontal lobe syndrome } \\
(\text { GRN 23; MAPT 9; C9ORF72 6) }\end{array}$ & $73.9 \%(17)$ & $53.3 \%(8)$ & 0.191 \\
\hline $\begin{array}{c}\text { Cortical sensory loss } \\
(G R N 24 ; M A P T \text { 9; C9ORF72 6) }\end{array}$ & $12.5 \%(3)$ & $20.0 \%(3)$ & 0.658 \\
\hline $\begin{array}{c}\text { Alien limb } \\
\text { (GRN 24; MAPT 9; C9ORF72 6) }\end{array}$ & $12.3 \%(3)$ & $20.0 \%(3)$ & 0.658 \\
\hline
\end{tabular}

\subsubsection{MAPT Mutations in CBS}

The MAPT gene (chr17q21.1) encodes microtubule-associated protein tau, whose main function is the modulation of microtubule architecture and spatial arrangement of cell structures [45].

$M A P T$ mutations prevent the binding of tau protein to microtubules and lead to the synthesis of isoforms that are susceptible to hyperphosphorylation and precipitation as insoluble fibrillar aggregates, which are also known as tangles [46]. The predominant aggregation of four-repeat ( $4 \mathrm{R} \mathrm{tau}$ ) or three-repeat ( $3 \mathrm{R}$ tau) isoforms as a consequence of exon 10 splicing led to different neurodegenerative patterns. 
Mutations in the MAPT gene inherited as an autosomal dominant trait are strongly associated with tauopathies. They are an established cause of FTD with parkinsonism-17 (FTDP-17) [47] and, less frequently, of PSP [48]. In rare cases, certain MAPT mutations can lead to a CBS presentation [49-55].

Nine cases of MAPT carriers from seven families presenting as CBS have been reported. Pathogenic MAPT mutations implicated in CBS are only missense variants, with the most frequent being P301S, which was identified in three patients.

The mean age at onset in carriers of MAPT mutations was 48.2 years (range: $27-70$ years), which is slightly lower than the mean age at onset for CBS.

A positive family history of parkinsonism or dementia resulted extremely frequent in $M A P T$ mutation carriers (7 out of 9 subjects, $78 \%$ of the total MAPT subgroup), confirming $M A P T$ mutations as highly penetrant [56].

The clinical description of MAPT cases highlighted the pervasive presence of motor impairment, showing the highest prevalence of tremor (both resting and postural), dystonia, and oculomotor dysfunction (vertical upgaze limitation and slowing of saccades were the main findings) among the different subgroups of patients (Figure 1A).

Memory, language, and cortical sensory functions were also often impaired in MAPT carriers (Figure 1B).

The neuroimaging data that were available for seven MAPT mutation carriers showed bilateral frontal and/or parietal atrophy with only mild asymmetry in four patients. In contrast, three cases presented marked asymmetric atrophy of the fronto-temporo-parietal areas. In two other patients, brain imaging was not available. Due to the small sample size and the variability of the MRI findings, it was not possible to identify a common neuroradiological pattern in MAPT carriers, who are generally reported to show a predominant anteromedial temporal lobe atrophy, which is often bilateral [57].

Two patients underwent 123 I ioflupane SPECT, revealing an asymmetrically reduced signal in the basal ganglia as in sporadic CBS.

Finally, two cases had confirmed CBD pathology by autopsy, with four-repeat-tau positive inclusions in neurons and glia as well as marked diffuse gliosis.

\subsubsection{C9ORF72 Expansion in CBS}

The C9ORF72 gene (chr9p21.2) encodes the C9ORF72 protein, which is located mainly in the cytoplasm of neurons as well as in presynaptic terminals. C9ORF72-like proteins are thought to regulate endosomal trafficking [58], nucleocytoplasmic transport [59], and RNA processing [60].

C9ORF72 contains an intronic hexanucleotide repeat (GGGGCC), whose expansion (>30 repeats) is the most common cause of familial autosomal dominant amyotrophic lateral sclerosis (ALS) and FTD with ALS [61]. Parkinsonian features have been reported in up to $35 \%$ of patients with C9ORF72 mutations [62].

Six unrelated cases harboring the C9ORF72 expansion displayed a phenotype presenting as CBS [63-66]. The mean age at onset was 50.2 years (range: 42-60 years). Positive family history for dementia was reported in all cases except one.

The clinical manifestations differentiating C9ORF72 patients from CBS cases carrying other mutations were the frequency and predominance of cognitive impairment and frontal dysexecutive syndrome (Figure 1B), manifesting with disinhibition, apathy, attention deficit, mutism, hyperphagia, and rituals.

Of the six reported patients, two showed asymmetric frontotemporal atrophy on MRI, and two presented generalized cortical atrophy; imaging was unavailable in the other two cases.

Evidence from the literature shows that C9ORF72 is associated with widespread brain atrophy that progresses with an antero-posterior gradient over time and involves the cerebellum [38].

None of the six cases underwent a neuropathological examination. 


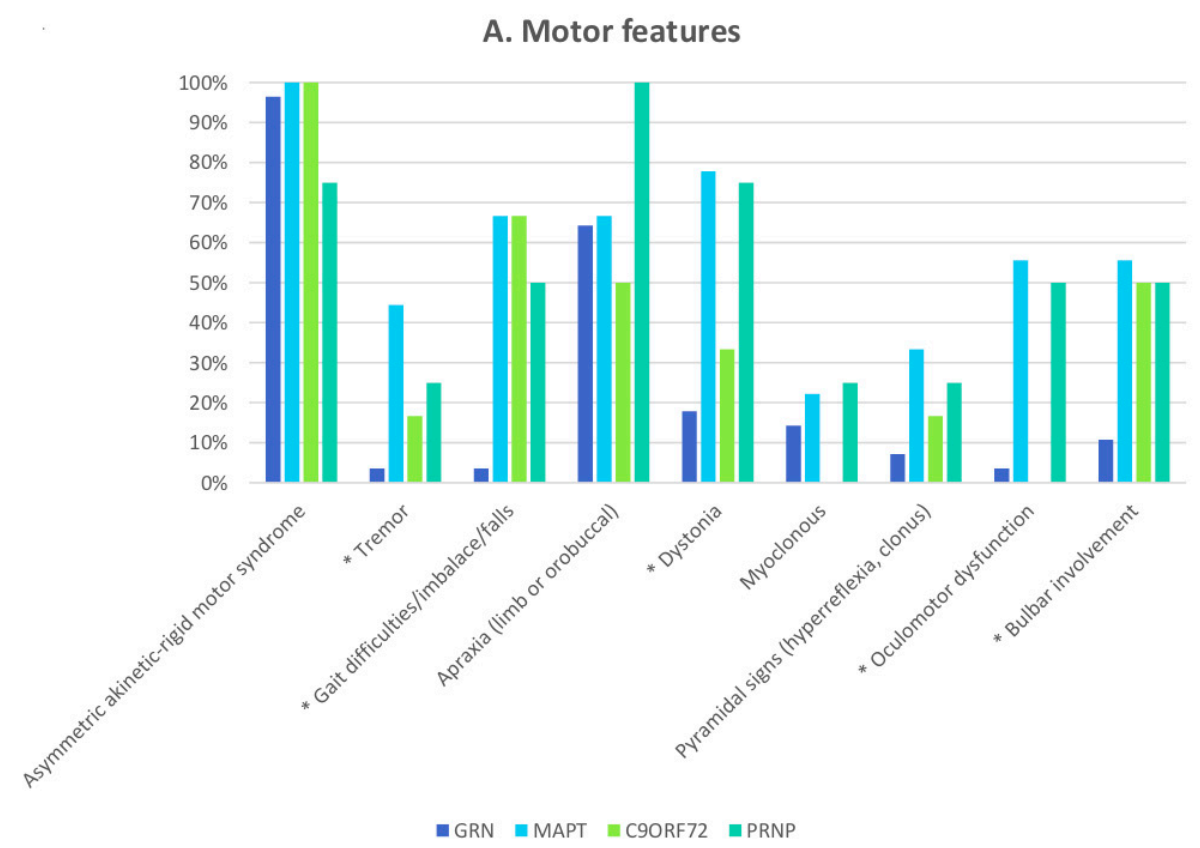

B. Cognitive and cortical features

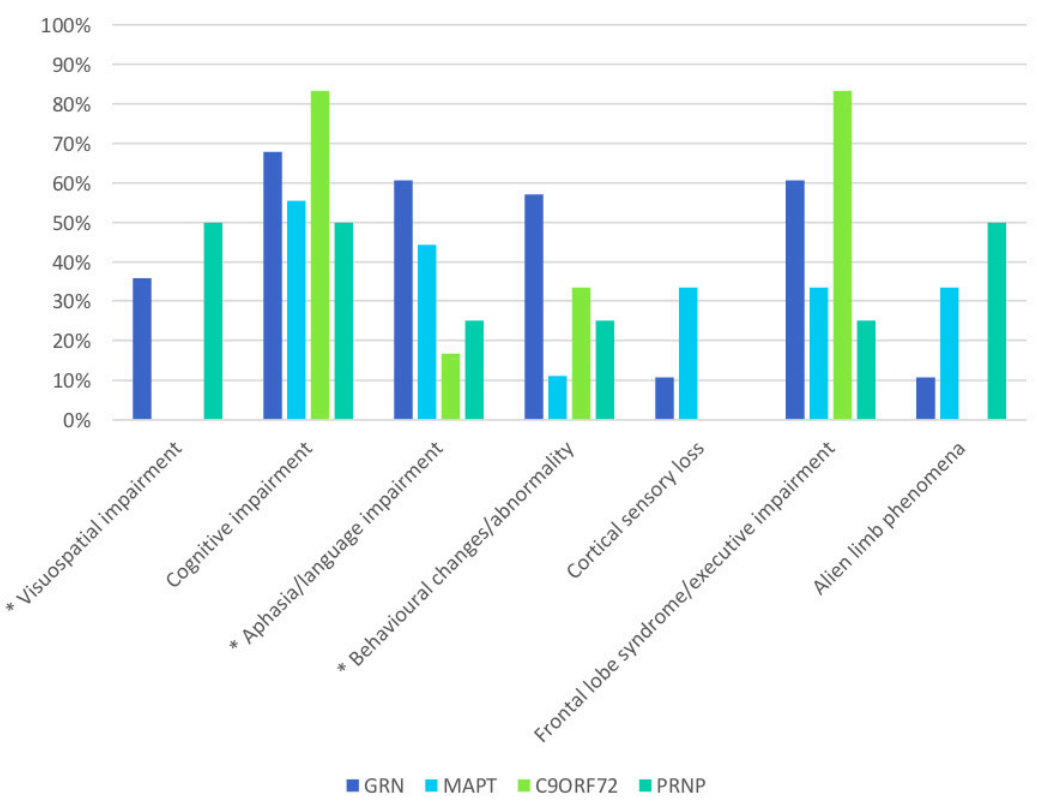

Figure 1. Histograms showing the frequency of motor $(\mathbf{A})$ and cognitive $(\mathbf{B})$ features in patients with CBS associated with mutations in GRN, MAPT, C9ORF72, and PRNP. The asterisk $\left(^{*}\right)$ marks clinical features that were statistically different between GRN patients and non-GRN cases, as reported in Table 2.

\subsubsection{PRNP Mutations in CBS}

Corticobasal syndrome can occur as an early manifestation in sporadic and genetic Creutzfeldt-Jakob disease (gCJD) [67-69].

gCJD presenting with CBS carries an autosomal dominant mutation of the prion protein (PRNP) gene, with E200K being the most common [70]. PRNP mutations cause the conversion of the encoded protein from the normal PrPC into the protease-resistant form, called PrPRes, which aggregates in the brain and destroys neuronal tissue [71]. 
We found four unrelated cases with gCJD presenting as CBS. The age at onset and the age at death were, respectively, 58.8 years (range $43-73$ ) and 60.5 years (range $45-73$ ) on average.

The clinical manifestations were similar to the CBS phenotype at the onset, but showed a rapidly progressive course, and all patients died within 1-2 years since the onset of the disease.

Only one subject had a positive family history of CJD.

Apraxia, myoclonus, and visuospatial impairment seem more frequent in this group, but this finding did not reach statistical significance, probably because of the small sample size. Similarities were seen between CBS patients with PRNP and MAPT mutations, with high recurrence in extrapyramidal symptoms, dystonia, oculomotor and bulbar dysfunction, cognitive impairment, and alien-limb phenomena (Figure 1).

MRI findings, when available, were essential for supporting the final diagnoses; in fact, cortical and deep gray matter hyperintensity on T2 and cortical ribboning on DWI were strongly suggestive of prion disease in at least two of the reported cases.

The neuropathology was available in three cases. Two revealed a typical prion pattern with spongiosis, neuronal loss, astrogliosis, and immunohistochemically detection of pathological prion protein. On the other hand, in a subject described by Jung et al. [72], the autopsy proved a CBD, with a neuronal tau pathology both in the cortex and in the basal ganglia. The genetic analysis did not reveal any mutation in the MAPT or GRN genes; instead, a homozygous 24 bp deletion in the octapeptide repeat region in the PRNP gene was detected.

\subsubsection{Other Genes}

One case of CBS characterized by asymmetric akinetic-rigid syndrome, limb dystonia, apraxia, and cognitive/behavioral changes was described in a patient affected by type 1 Gaucher's disease [73] with compound heterozygous GBA mutations (N370S/L444P). Pilotto et al. [74] screened the most common GBA mutations in 39 patients with a clinical diagnosis of probable CBS and found two patients with a heterozygous N370S variation. These findings are interesting since they indicate that N370S GBA mutations may cause heterogeneous clinical phenotypes, aside from PD and dementia with Lewy bodies.

A unique family affected by cerebrotendinous xanthomatosis due to autosomal recessive mutations in CYP27A1 presented with asymmetric parkinsonism, apraxia, and dystonia, resembling a CBS phenotype [75].

In a Belgian study, mutation analysis of $C H M P 2 B$ was performed in 134 FTLD patients, seven CBS patients, and five PSP patients. A missense mutation in exon 5 of $C H M P 2 B$ (N143S) was found in a single patient with CBS [76].

In an extensive screening for LRRK2 mutations [77], among eight patients found to carry the common G2019S mutation, one had previously received a diagnosis of CBS. LRRK2 autosomal dominant mutations are associated with typical forms of PD, and only a few exceptions reporting different phenotypes exist in literature [78]. However, the G2019S mutation has been reported in some cases with tau-predominant pathology [79], suggesting a possible association with different neurodegenerative disorders as well.

Navarro et al. [80] described a family with pathologically confirmed cases of earlyonset Alzheimer's disease linked to a mutation of the presenilin-1 gene (PSEN-1); one member of the family developed an atypical phenotype, with left-upper-limb bradykinesia and dystonia, myoclonus, apraxia confined to the left limbs, hemispatial neglect, and frontal dementia, thus mimicking CBS. The clinical features were coherent with the MRI findings, showing severe asymmetric cortical atrophy (right more than left).

Recently, a case of probable CBS was described for the first time in a patient with an $A P P$ mutation and a very relevant positive family history for dementia, parkinsonism, and behavioral disorders [81]. In this patient, as in the previous one with PSEN-1 mutation, CBS was probably underpinned by AD pathology, since mutations in APP, PSEN1, and PSEN2 are the pathogenic cause of autosomal dominant AD. 
In a large study evaluating FUS and TARDBP (i.e., TDP-43) mutations in 158 FTD and 70 CBS patients, the authors identified the TARDBP N267S mutation in a CBS patient. Additionally, the sequencing analysis of FUS revealed a heterozygous insertion in exon 5 Gly175-Gly176 ins GG in a patient diagnosed with CBS, but this variant was also found among normal controls, making it thus unlikely to be pathogenetic [82].

Finally, two first cousins were reported as having asymmetric parkinsonism, apraxia, myoclonus, dystonia, cortical sensory loss, and ataxic gait, which clearly resembled CBS [83]. Post-mortem examination of both patients was consistent with CBD. Since genetic tests for FXTAS, GRN, MAPT, and LRRK2 mutations were negative, both underwent exome sequencing, which revealed mutations in MRS2 and ZHX2 genes, and were predicted as possibly pathogenic. MRS2 encodes for a Mg2+ channel, while the ZHX2 gene product acts as a transcriptional regulator implicated in neuronal differentiation. The roles of MRS2 and ZHX2 in CBD remain to be further investigated.

\subsection{Genetic Risk Factors Associated with $C B S$ and $C B D$}

So far, two major genetic risk factors have been found to be associated with CBS: homozygosity for the MAPT H1c haplotype and MOBP (myelin-associated oligodendrocyte basic protein).

The H1 MAPT haplotype confers a higher risk of developing both PSP (odds ratio of 5.5) and CBS/CBD (odds ratio of 3.7) [84-86]. Interestingly, the H1 haplotype increases the transcription of four-repeat tau isoforms [87], which are more prone to aggregation, leading to the characteristic anatomopathological stigmata of tauopathies. Litvan et al. [88] also highlighted that the $\mathrm{H} 1 / \mathrm{H} 1$ genotype was associated with a worse motor function in terms of Unified Parkinson's Disease Rating Scale III scores; they also described a trend toward shorter survival in the $\mathrm{H} 1$ / H1 group, but the study was underpowered in finding a statistically significant influence on survival.

However, the role of the $\mathrm{H} 1 / \mathrm{H} 1$ tau genotype remains unclear, since it is also common in the general population (76.6\%) [89].

Considering risk factors other than $M A P T$, Kouri et al. [90] performed a genomewide association study (GWAS) of 152 pathologically confirmed CBD cases and identified SNPs at 3p22 MOBP, showing another genetic risk factor shared by CBD and PSP. No clinical information was reported; therefore, it is impossible to establish whether those cases displayed a CBS phenotype.

Similarly, Yokoyama et al. [91] identified novel genetic overlap among CBD, PSP, and FTD within loci representing CXCR4 (C-X-C chemokine receptor type 4), EGFR (epidermal growth factor receptor), and GLDC (glycine decarboxylase). The authors suggested that these genes may influence the regional pattern of volume loss and, thus, the disease phenotype; for instance, patients with $M A P T$ and CXCR4 susceptibility variants may have a higher risk of developing PSP, while patients with $M A P T, M O B P$, and GLDC may be at greater risk for CBD/CBS or FTD than PSP.

Finally, an Italian study [92] suggested that the vascular endothelial growth factor (VEGF) A-G-G haplotype confers an increased risk of developing tauopathies, as it is overrepresented in both PSP $(\mathrm{OR}=6.64)$ and CBS $(\mathrm{OR}=5.20)$, as well as FTD.

\section{Discussion}

Several genetic conditions may phenotypically present as CBS, but usually show additional features that may provide important clues for the genetic diagnosis. We integrated these features into a diagnostic algorithm and proposed a three-step diagnostic approach (Figure 2) according to the findings.

First, an accurate family health history collection is of great importance. As CBS is more frequently sporadic, the presence of other affected family members represents the first hint in screening genetic forms.

A dominant family history of adult-onset parkinsonism or dementia would point mainly towards GRN, MAPT, and C9ORF72; a recessive pattern of inheritance or a more 
complex neurological phenotype may suggest other diseases less frequently associated with CBS-like phenotypes, such as cerebrotendinous xanthomatosis. A pedigree that reports PD or Gaucher disease may raise the suspicion of GBA mutations. Importantly, a positive family history for psychiatric disorders and motor neuron disease may lead to prioritization of C9ORF72 mutation screening.

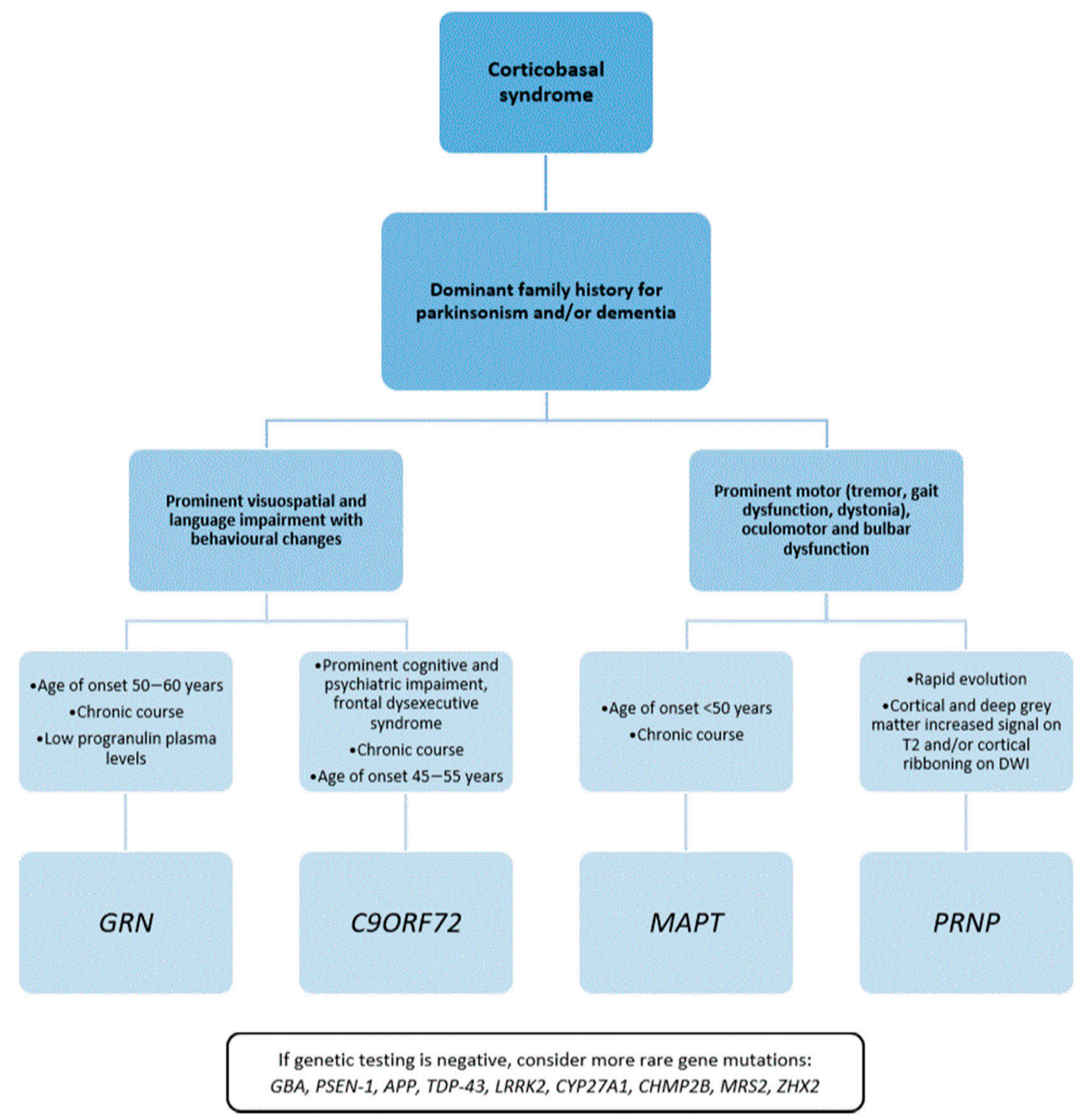

Figure 2. Diagnostic algorithm for screening genetic causes of CBS.

Notably, a negative family history does not rule out genetic disorders and may be due to reduced penetrance, variable age at onset, or de novo mutations.

Secondly, some distinct clinical features may suggest a specific mutation (Table S1).

GRN, C9ORF72, and PSEN-1 carriers seem to have predominant cortical involvement, clinically presenting with visuospatial and language impairment and behavioral changes. Conversely, MAPT and PRNP carriers more frequently develop motor symptoms suggestive of subcortical and brainstem areas, such as dystonia, tremor, gait dysfunction, and oculomotor and bulbar dysfunction. Therefore, according to the more affected function, i.e., cognitive or motor, a different subset of mutations should be taken into consideration.

As a third point, features to be considered are the age of onset and the disease course.

The mean age at onset of sporadic CBS is from 50 to 60 years; thus, a younger age at the onset of symptoms should suggest a genetic form of CBS. 
According to available evidence, there is a gradient in the symptom onset age according to the specific causative mutation: MAPT carriers have an earlier onset, followed by C9ORF72 and GRN carriers [93]. Our review confirms these findings and suggests considering MAPT mutations in patients with a clinical onset before the age of 50 .

The clinical course of sporadic CBS is that of a chronic neurodegenerative condition with a median survival of 6 to 7 years. Thus, a more rapid progression should be considered a red flag and may suggest a prion disease or an acquired condition, such as autoimmune or vascular disorders [94].

Lastly, biochemical and radiological data may support the diagnosis. The evaluation of plasmatic progranulin levels is useful for raising the suspicion of a GRN mutation [95] and should be performed even in the absence of positive family history for movement disorders.

EEG showing periodic sharp-wave complexes and MRI results displaying gray matter hyperintensity on T2 and cortical ribboning on DWI are strongly suggestive of prion disease.

A single genetic mutation may not be sufficient for determining a CBS phenotype, which likely requires additional hits. Gene expression is influenced by modulation of genetic and environmental factors, whose effect can induce, for example, the expression of a GRN mutation as CBS rather than FTD. Further studies exploring whole-genome variants of individuals with one of the mutations also described in CBS may shed light on the specific genetic architecture underling CBS.

Identifying genetic variants underlying CBS has a great practical relevance, since it allows appropriate family counseling and the possibility to be enrolled in clinical trials with disease-modifying treatments. This process is currently ongoing for GRN and GBA mutation carriers, but will likely be extended to other gene variants in the future.

Finally, considering the data from the literature reported here and prompted by our and others' experience of CBS cases with GBA or AD gene mutations [74,81], we strongly encourage to screen CBS patients for genes correlated with other neurodegenerative diseases when more frequent mutations have been excluded.

\section{Conclusions}

The knowledge of the genetic background of CBS is expanding rapidly, and it helps to improve diagnostic accuracy and the understanding of the underlying molecular pathogenetic processes.

Positive family history and an earlier age at onset are the two main clues that should lead clinicians to suspect and test for genetic conditions. However, an age at onset comparable with that of sporadic cases should not rule out the possibility of genetic testing, especially if $G R N$ is suspected.

Our review of genotype-phenotype correlation in corticobasal syndrome emphasizes the importance of a complete and in-depth clinical assessment. In fact, although there is a significant overlap in terms of clinical presentation, there may be some demographical, clinical, biochemical, and radiological features that are significantly evocative of mutations in specific genes.

Supplementary Materials: The following are available online at https:/ / www.mdpi.com/2073-440 9/10/1/171/s1, Table S1: Analysis of clinical features of GRN, MAPT and C9ORF72 carriers.

Author Contributions: F.A.: Conceptualization, Methodology, Writing—original draft preparation; G.L.: Data curation, Writing —original draft preparation; M.V.: Data curation, Writing —original draft preparation; E.M.: Writing - reviewing and editing. N.B.: Supervision; M.C.S.: Supervision, Writing — reviewing and editing; M.P.: Supervision, Writing—reviewing and editing; G.F.: Supervision, Writing—reviewing and editing; A.D.F.: Supervision, Writing—reviewing and editing. All authors have read and agreed to the published version of the manuscript.

Funding: This research did not receive any specific grants from funding agencies in the public, commercial, or not-for-profit sectors. 
Acknowledgments: We thank the "Associazione Centro Dino Ferrari" and the "Fresco Institute" for their support.

Conflicts of Interest: The authors declare no conflict of interest.

\section{References}

1. Chahine, L.M.; Rebeiz, T.; Rebeiz, J.J.; Grossman, M.; Gross, R.G. Corticobasal syndrome: Five new things. Neurol. Clin. Pract. 2014, 4, 304-312. [CrossRef] [PubMed]

2. Boxer, A.L.; Geschwind, M.D.; Belfor, N.; Gorno-Tempini, M.L.; Schauer, G.F.; Miller, B.L.; Weiner, M.W.; Rosen, H.J. Patterns of Brain Atrophy That Differentiate Corticobasal Degeneration Syndrome From Progressive Supranuclear Palsy. Arch. Neurol. 2006, 63, 81-86. [CrossRef] [PubMed]

3. Togasaki, D.M.; Tanner, C.M. Epidemiologic aspects. Adv. Neurol. 2000, 82, 53-59. [PubMed]

4. Wenning, G.K.; Litvan, I.; Jankovic, J.; Granata, R.; Mangone, C.A.; McKee, A.; Poewe, W.; Jellinger, K.; Chaudhuri, K.R.; D'Olhaberriague, L.; et al. Natural history and survival of 14 patients with corticobasal degeneration confirmed at postmortem examination. J. Neurol. Neurosurg. Psychiatry 1998, 64, 184-189. [CrossRef] [PubMed]

5. Murray, R.; Neumann, M.; Forman, M.S.; Farmer, J.; Massimo, L.; Rice, A.; Miller, B.L.; Johnson, J.K.; Clark, C.M.; Hurtig, H.I.; et al. Cognitive and motor assessment in autopsy-proven corticobasal degeneration. Neurology 2007, 68, 1274-1283. [CrossRef]

6. Lang, A.E.; Riley, D.E.; Bergeron, C. Cortico-Basal Ganglionic Degeneration. In Neurodegenerative Diseases; Calne, D.B., Ed.; WB Saunders: Phila-Delphia, PA, USA, 1994; p. 877.e94.

7. Boeve, B.F.; Lang, A.E.; Litvan, I. Corticobasal degeneration and its relationship to progressive supranuclear palsy and frontotemporal dementia. Ann. Neurol. 2003, 54 (Suppl. S5), S15e19. [CrossRef]

8. Bak, T.H.; Hodges, J.R.; Thomas, H.B. Corticobasal Degeneration: Clinical Aspects. In Handbook of Clinical Neurology; Duyckaerts, C., Litvan, I., Eds.; Elsevier: Amsterdam, The Netherlands, 2008; Volume 89, p. 509.e21.

9. Armstrong, M.J.; Litvan, I.; Lang, A.E.; Bak, T.H.; Bhatia, K.P.; Borroni, B.; Boxer, A.L.; Dickson, D.W.; Grossman, M.; Hallett, M.; et al. Criteria for the diagnosis of corticobasal degeneration. Neurology 2013, 80, 496-503. [CrossRef]

10. Wadia, P.M.; Lang, A.E. The many faces of corticobasal degeneration. Park. Relat. Disord. 2007, 13, S336-S340. [CrossRef]

11. Boeve, B.F.; Maraganore, D.M.; Parisi, J.E.; Ahlskog, J.E.; Graff-Radford, N.; Caselli, R.J.; Dickson, D.W.; Kokmen, E.; Petersen, R.C. Pathologic heterogeneity in clinically diagnosed corticobasal degeneration. Neurology 1999, 53, 795. [CrossRef]

12. Baizabal-Carvallo, J.F.; Jankovic, J. Parkinsonism, movement disorders and genetics in frontotemporal dementia. Nat. Rev. Neurol. 2016, 12, 175-185. [CrossRef] [PubMed]

13. He, Z.; Bateman, A. Progranulin (granulin-epithelin precursor, PC-cell-derived growth factor, acrogranin) mediates tissue re-pair and tumorigenesis. J. Mol. Med. 2003, 81, 600-612. [CrossRef] [PubMed]

14. Chitramuthu, B.P.; Bennett, H.P.J.; Bateman, A. Progranulin: A new avenue towards the understanding and treatment of neurodegenerative disease. Brain 2017, 140, 3081-3104. [CrossRef] [PubMed]

15. He, Z.; Ismail, A.; Kriazhev, L.; Sadvakassova, G.; Bateman, A. Progranulin (PC-cell-derived growth factor/acrogranin) regulates invasion and cell survival. Cancer Res. 2002, 62, 5590-5596. [PubMed]

16. Kumar-Singh, S. Progranulin and TDP-43: Mechanistic Links and Future Directions. J. Mol. Neurosci. 2011, 45, 561-573. [CrossRef] [PubMed]

17. Daniel, R.; He, Z.; Carmichael, K.P.; Halper, J.; Bateman, A. Cellular Localization of Gene Expression for Progranulin. J. Histochem. Cytochem. 2000, 48, 999-1009. [CrossRef]

18. Cruts, M.; Gijselinck, I.; van der Zee, J.; Engelborghs, S.; Wils, H.; Pirici, D.; Rademakers, R.; Vandenberghe, R.; Dermaut, B.; Martin, J.J.; et al. Null mutations in progranulin cause ubiquitin-positive frontotemporal dementia linked to chro-mosome $17 \mathrm{q} 21$. Nature 2006, 442, 916-919. [CrossRef]

19. Karch, C.M.; Ezerskiy, L.A.; Redaelli, V.; Giovagnoli, A.R.; Tiraboschi, P.; Pelliccioni, G.; Pelliccioni, P.; Kapetis, D.; D' Amato, I.; Piccoli, E.; et al. Missense mutations in progranulin gene associated with frontotemporal lobar degeneration: Study of pathogenetic features. Neurobiol. Aging 2016, 38, 215.e1-215.e12. [CrossRef]

20. Finch, N.; Baker, M.; Crook, R.; Swanson, K.; Kuntz, K.; Surtees, R.; Bisceglio, G.; Rovelet-Lecrux, A.; Boeve, B.; Petersen, R.C.; et al. Plasma progranulin levels predict progranulin mutation status in frontotemporal dementia patients and asymptomatic family members. Brain 2009, 132, 583-591. [CrossRef]

21. Galimberti, D.; Bertram, K.; Formica, A.; Fenoglio, C.; Cioffi, S.M.; Arighi, A.; Scarpini, E.; Colosimo, C. Plasma Screening for Progranulin Mutations in Patients with Progressive Supranuclear Palsy and Corticobasal Syndromes. J. Alzheimers Dis. 2016, 53, 445-449. [CrossRef]

22. Gass, J.; Cannon, A.; MacKenzie, I.R.; Boeve, B.; Baker, M.; Adamson, J.; Crook, R.; Melquist, S.; Kuntz, K.; Petersen, R.; et al. Mutations in progranulin are a major cause of ubiquitin-positive frontotemporal lobar degeneration. Hum. Mol. Genet. 2006, 15, 2988-3001. [CrossRef]

23. Van Swieten, J.C.; Heutink, P. Mutations in progranulin $(G R N)$ within the spectrum of clinical and pathological pheno-types of frontotemporal dementia. Lancet Neurol. 2008, 7, 965-974. [CrossRef]

24. Kelley, B.J.; Haidar, W.; Boeve, B.; Baker, M.; Graff-Radford, N.R.; Krefft, T.; Frank, A.R.; Jack, C.R.; Shiung, M.; Knopman, D.S.; et al. Prominent phenotypic variability associated with mutations in Progranulin. Neurobiol. Aging 2009, 30, 739-751. [CrossRef] [PubMed] 
25. Le Ber, I.; Camuzat, A.; Hannequin, D.; Pasquier, F.; Guedj, E.; Rovelet-Lecrux, A.; Hahn-Barma, V.; Van Der Zee, J.; Clot, F.; Bakchine, S.; et al. Phenotype variability in progranulin mutation carriers: A clinical, neuropsychological, imaging and genetic study. Brain 2008, 131, 732-746. [CrossRef] [PubMed]

26. Coppola, C.; Rossi, G.; Barbarulo, A.M.; Di Fede, G.; Foglia, C.; Piccoli, E.; Piscosquito, G.; Saracino, D.; Tagliavini, F.; Cotrufo, R. A progranulin mutation associated with cortico-basal syndrome in an Italian family expressing different phenotypes of fronto-temporal lobar degeneration. Neurol. Sci. 2011, 33, 93-97. [CrossRef] [PubMed]

27. Benussi, L.; Binetti, G.; Sina, E.; Gigola, L.; Bettecken, T.; Meitinger, T.; Ghidoni, R. A novel deletion in progranulin gene is associated with FTDP-17 and CBS. Neurobiol. Aging 2008, 29, 427-435. [CrossRef]

28. Canafoglia, L.; Morbin, M.; Scaioli, V.; Pareyson, D.; D’Incerti, L.; Fugnanesi, V.; Tagliavini, F.; Berkovic, S.F.; Franceschetti, S. Recurrent generalized seizures, visual loss, and palinopsia as phenotypic features of neuronal ceroid lipofuscinosis due to progranulin gene mutation. Epilepsia 2014, 55, e56-e59. [CrossRef]

29. Kamate, M.; Detroja, M.; Hattiholi, V. Neuronal ceroid lipofuscinosis type-11 in an adolescent. Brain Dev. 2019, 41, 542-545. [CrossRef]

30. Beck, J.; Rohrer, J.D.; Campbell, T.; Isaacs, A.; Morrison, K.E.; Goodall, E.F.; Warrington, E.K.; Stevens, J.; Revesz, T.; Holton, J.; et al. A distinct clinical, neuropsychological and radiological phenotype is associated with progranulin gene mutations in a large UK series. Brain 2008, 131, 706-720. [CrossRef]

31. Yu, C.E.; Bird, T.D.; Bekris, L.M.; Montine, T.J.; Leverenz, J.B.; Steinbart, E.; Van Deerlin, V.M. The Spectrum of Mutations in Progranulin. A Collaborative Study Screening 545 Cases of Neurodegeneration. Arch. Neurol. 2010, 67, 161-170. [CrossRef]

32. Taghdiri, F.; Sato, C.; Ghani, M.; Moreno, D.; Rogaeva, E.; Tartaglia, M.C. Novel GRN Mutations in Patients with Corticobasal Syndrome. Sci. Rep. 2016, 6, 22913. [CrossRef]

33. Benussi, L.; Ghidoni, R.; Pegoiani, E.; Moretti, D.V.; Zanetti, O.; Binetti, G. Progranulin Leu271LeufsX10 is one of the most common FTLD and CBS associated mutations worldwide. Neurobiol. Dis. 2009, 33, 379-385. [CrossRef] [PubMed]

34. Spina, S.; Murrell, J.R.; Huey, E.D.; Wassermann, E.M.; Pietrini, P.; Grafman, J.; Ghetti, B. Corticobasal syndrome associated with the A9D progranulin mutation. J. Neuropathol. Exp. Neurol. 2007, 66, 892-900. [PubMed]

35. Guerreiro, R.; Santana, I.; Bras, J.; Revesz, T.; Rebelo, O.; Bs, M.H.R.; Santiago, B.; Oliveira, C.R.; Singleton, A.; Hardy, J. Novel progranulin mutation: Screening for PGRN mutations in a Portuguese series of FTD/CBS cases. Mov. Disord. 2008, 23, 1269-1273. [CrossRef] [PubMed]

36. Passov, V.; Gavrilova, R.H.; Strand, E.; Cerhan, J.H.; Josephs, K.A. Sporadic Corticobasal Syndrome With Progranulin Mutation Presenting as Progressive Apraxic Agraphia. Arch. Neurol. 2011, 68, 376-380. [CrossRef]

37. Dopper, E.G.P.; Seelaar, H.; Chiu, W.Z.; De Koning, I.; Van Minkelen, R.; Baker, M.C.; Rozemuller, A.J.M.; Rademakers, R.; Van Swieten, J.C. Symmetrical Corticobasal Syndrome Caused by a Novel c.314dup Progranulin Mutation. J. Mol. Neurosci. 2011, 45, 354-358. [CrossRef]

38. Whitwell, J.L.; Weigand, S.D.; Boeve, B.F.; Senjem, M.L.; Gunter, J.L.; DeJesus-Hernandez, M.; Rutherford, N.J.; Baker, M.; Knopman, D.S.; Wszolek, Z.K.; et al. Neuroimaging signatures of frontotemporal dementia genetics: C9ORF72, tau, progranulin and sporadics. Brain 2012, 135, 794-806. [CrossRef]

39. Whitwell, J.L.; Jack, C.R.; Baker, M.; Rademakers, R.; Adamson, J.; Boeve, B.F.; Knopman, D.S.; Parisi, J.F.; Petersen, R.C.; Dickson, D.W.; et al. Voxel-Based Morphometry in Frontotemporal Lobar Degeneration With Ubiquitin-Positive Inclusions With and Without Progranulin Mutations. Arch. Neurol. 2007, 64, 371-376. [CrossRef]

40. Rohrer, J.D.; Beck, J.; Warren, J.D.; King, A.; Sarraj, S.A.; Holton, J.L.; Revesz, T.; Collinge, J.; Mead, S. Corticobasal syndrome associated with a novel 1048_1049insG progranulin mutation. J. Neurol. Neurosurg. Psychiatry 2009, 80, 1297-1298. [CrossRef]

41. Masellis, M.; Momeni, P.; Meschino, W.; Heffner, R.; Elder, J.; Sato, C.; Liang, Y.; George-Hyslop, P.S.; Hardy, J.; Bilbao, J.; et al Novel splicing mutation in the progranulin gene causing familial corticobasal syndrome. Brain 2006, 129, 3115-3123. [CrossRef]

42. Josephs, K.A.; Holton, J.L.; Rossor, M.N.; Godbolt, A.K.; Ozawa, T.; Strand, K.; Khan, N.; Al Sarraj, S.; Revesz, T. Frontotemporal lobar degeneration and ubiquitin immunohistochemistry. Neuropathol. Appl. Neurobiol. 2004, 30, 369-373.

43. Sampathu, D.M.; Neumann, M.; Kwong, L.K.; Chou, T.T.; Micsenyi, M.; Truax, A.; Lee, V.M.Y. Pathological heterogeneity of frontotemporal lobar degeneration with ubiqui-tin-positive inclusions delineated by ubiquitin immunohistochemistry and novel monoclonal antibodies. Am. J. Pathol. 2006, 169, 1343-1352. [PubMed]

44. Mackenzie, I.R.A.; Baborie, A.; Pickering-Brown, S.; Du Plessis, D.; Jaros, E.; Perry, R.H.; Mann, D.M. Heterogeneity of ubiquitin pathology in frontotemporal lobar degenera-tion: Classification and relation to clinical phenotype. Acta Neuropathol. 2006, 112, 539-549. [PubMed]

45. Cleveland, D.W.; Hwo, S.-Y.; Kirschner, M.W. Physical and chemical properties of purified tau factor and the role of tau in microtubule assembly. J. Mol. Biol. 1977, 116, 227-247. [CrossRef]

46. Kouri, N.; Whitwell, J.L.; Josephs, K.A.; Rademakers, R.; Dickson, D.W. Corticobasal degeneration: A pathologically distinct 4R tauopathy. Nat. Rev. Neurol. 2011, 7, 263-272. [CrossRef] [PubMed]

47. Spillantini, M.G.; Van Swieten, J.C.; Goedert, M. Tau gene mutations in frontotemporal dementia and parkinsonism linked to chromosome 17 (FTDP-17). Neurogenetics 2000, 2, 193-205. [CrossRef]

48. Rohrer, J.D.; Paviour, D.; Vandrovcova, J.; Hodges, J.; De Silva, R.; Rossor, M. Novel L284R MAPT Mutation in a Family with an Autosomal Dominant Progressive Supranuclear Palsy Syndrome. Neurodegener. Dis. 2011, 8, 149-152. [CrossRef] [PubMed] 
49. Casseron, W.; Azulay, J.P.; Guedj, E.; Gastaut, J.L.; Pouget, J. Familial autosomal dominant cortico-basal degeneration with the P301S mutation in the tau gene: An example of phenotype variability. J. Neurol. 2005, 252, 1546-1548. [CrossRef]

50. Gatto, E.M.; Allegri, R.F.; Da Prat, G.; Mendez, P.C.; Hanna, D.S.; Dorschner, M.O.; Surace, E.I.; Zabetian, C.P.; Mata, I.F. Intrafamili-al variable phenotype including corticobasal syndrome in a family with p.P301L mutation in the MAPT gene: First report in South America. Neurobiol. Aging 2017, 53, 195.e11-195.e17.

51. Rossi, G.; Marelli, C.; Farina, L.; Laurà, M.; Basile, A.M.; Ciano, C.; Tagliavini, F.; Pareyson, D. The G389R mutation in the MAPT gene presenting as sporadic corticobasal syndrome. Mov. Disord. 2008, 23, 892-895. [CrossRef]

52. Marshall, C.R.; Guerreiro, R.; Thust, S.; Fletcher, P.; Rohrer, J.D.; Fox, N.C. A Novel MAPT Mutation Causing Corticobasal Syndrome Led by Progressive Apraxia of Speech. J. Alzheimers Dis. 2015, 48, 923-926. [CrossRef]

53. Bugiani, O.; Murrell, J.R.; Giaccone, G.; Hasegawa, M.; Ghigo, G.; Tabaton, M.; Morbin, M.; Primavera, A.; Carella, F.; Solaro, C.; et al. Frontotemporal Dementia and Corticobasal Degen-eration in a family with a P301S mutation in tau. J. Neuropathol. Exp. Neurol. 1999, 58, 667-677. [PubMed]

54. Kouri, N.; Carlomagno, Y.; Baker, M.; Liesinger, A.M.; Caselli, R.J.; Wszolek, Z.K.; Petrucelli, L.; Boeve, B.F.; Parisi, J.E.; Josephs, K.A.; et al. Novel mutation in MAPT exon 13 (p.N410H) causes corticobasal degeneration. Acta Neuropathol. 2014, 127, $271-282$. [CrossRef] [PubMed]

55. Ahmed, S.; Fairen, M.D.; Sabir, M.S.; Pastor, P.; Ding, J.; Ispierto, L.; Butala, A.; Morris, C.M.; Schulte, C.; Gasser, T.; et al. MAPT p.V363I mutation. Neurol. Genet. 2019, 5, e347. [CrossRef] [PubMed]

56. Greaves, C.V.; Rohrer, J.D. An update on genetic frontotemporal dementia. J. Neurol. 2019, 266, 2075-2086. [CrossRef]

57. Rohrer, J.D.; Ridgway, G.R.; Modat, M.; Ourselin, S.; Mead, S.; Fox, N.C.; Rossor, M.N.; Warren, J.D. Distinct profiles of brain atrophy in frontotemporal lobar degeneration caused by progranulin and tau mutations. NeuroImage 2010, 53, 1070-1076. [CrossRef]

58. Farg, M.A.; Sundaramoorthy, V.; Sultana, J.M.; Yang, S.; Atkinson, R.A.; Levina, V.; Halloran, M.A.; Gleeson, P.A.; Blair, I.P.; Soo, K.Y.; et al. C9ORF72, implicated in amytrophic lateral sclerosis and frontotemporal dementia, regulates endoso-mal trafficking. Hum. Mol. Genet. 2014, 23, 3579-3595.

59. Zhang, K.; Donnelly, C.J.; Haeusler, A.R.; Grima, J.C.; Machamer, J.B.; Steinwald, P.; Daley, E.L.; Miller, S.J.; Cunningham, K.M.; Vidensky, S.; et al. The C9ORF72 repeat expansion disrupts nucleocytoplasmic transport. Nat. Cell Biol. 2015, 525, 56-61. [CrossRef]

60. Barker, H.V.; Niblock, M.; Lee, Y.-B.; Shaw, P.; Gallo, J.-M. RNA Misprocessing in C9ORF72-Linked Neurodegeneration. Front. Cell. Neurosci. 2017, 11. [CrossRef]

61. DeJesus-Hernandez, M.; MacKenzie, I.R.; Boeve, B.F.; Boxer, A.L.; Baker, M.; Rutherford, N.J.; Nicholson, A.M.; Finch, N.A.; Flynn, H.; Adamson, J.; et al. Expanded GGGGCC Hexanucleotide Repeat in Noncoding Region of C9ORF72 Causes Chromosome 9p-Linked FTD and ALS. Neuron 2011, 72, 245-256. [CrossRef]

62. Boeve, B.; Boylan, K.B.; Graff-Radford, N.R.; DeJesus-Hernandez, M.; Knopman, D.S.; Pedraza, O.; Vemuri, P.; Jones, D.; Lowe, V.; Murray, M.E.; et al. Characterization of frontotemporal dementia and/or amyotrophic lateral sclerosis associated with the GGGGCC repeat expansion in C9ORF72. Brain 2012, 135, 765-783. [CrossRef]

63. Lesage, S.; Le Ber, I.; Condroyer, C.; Brousolle, E.; Gabelle, A.; Thobois, S. The analysis of C9ORF72 repeat expansions are a rare genetic cause of parkinsonism. Brain 2013, 136, 385-391. [CrossRef] [PubMed]

64. Schottlaender, L.V.; Polke, J.M.; Ling, H.; MacDoanld, N.D.; Tucci, A.; Nanji, T.; Pittman, A.; De Silva, R.; Holton, J.L.; Revesz, T.; et al. The analysis of C9ORF72 repeat expansions in a large series of clinically and pathologically diagnosed cases with atypical parkinsonism. Neurobiol. Aging 2015, 36, 1221.e1-1221.e6. [CrossRef] [PubMed]

65. Lindquist, S.G.; Duno, M.; Batbayli, M.; Puschmann, A.; Braendgaard, H.; Mardosiene, S.; Svenstrup, K.; Pinborg, L.H.; Vestergaard, K.; Hjermind, L.E.; et al. Corticobasal and ataxia syndromes widen the spectrum of C9ORF72 hexanucleotide expansion disease. Clin. Genet. 2013, 83, 279-283. [CrossRef] [PubMed]

66. Anor, C.J.; Xi, Z.; Zhang, M.; Moreno, D.; Sato, C.; Rogaeva, E.; Tartaglia, C. Mutation analysis of C9ORF72 in patients with corticobasal syndrome. Neurobiol. Aging 2015, 36, 2905.e1-2905.e5. [CrossRef] [PubMed]

67. Necpál, J.; Stelzer, M.; Koščová, S.; Patarák, M. A Corticobasal Syndrome Variant of Familial Creutzfeldt-Jakob Disease with Stroke-Like Onset. Case Rep. Neurol. Med. 2016, 2016, 1-3. [CrossRef]

68. Lim, J.G.; Oh, E.; Park, S.; Kim, Y.-S.; Lee, A.Y. Familial Creutzfeldt-Jakob disease with M232R mutation presented with corticobasal syndrome. Neurol. Sci. 2014, 36, 1291-1293. [CrossRef]

69. Mallucci, G.R.; Campbell, T.A.; Dickinson, A.; Beck, J.; Holt, M.; Plant, G.; De Pauw, K.W.; Hakin, R.N.; Clarke, C.E.; Howell, S.; et al. Inherited prion disease with an alanine to valine mutation at codon 117 in the prion protein gene. Brain 1999, 122, $1823-1837$. [CrossRef]

70. Kovacs, G.G.; Seguin, J.; Quadrio, I.; Höftberger, R.; Kapás, I.; Streichenberger, N.; Biacabe, A.G.; Meyronet, D.; Sciot, R.; Vandenberghe, R.; et al. Genetic Creutzfeldt-Jakob disease associated with the E200K mutation: Characterization of a complex proteinopathy. Acta Neuropathol. 2011, 121, 39-57. [CrossRef]

71. Prusiner, S.B.; Scott, M.R. GENETICS OF PRIONS. Annu. Rev. Genet. 1997, 31, 139-175. [CrossRef]

72. Jung, H.H.; Bremer, J.; Streffer, J.R.; Virdee, K.; Spillantini, M.G.; Crowther, R.A.; Brugger, P.; Van Broeckhoven, C.; Aguzzi, A.; Tolnay, M. Phenotypic Variation of Autosomal-Dominant Corticobasal Degeneration. Eur. Neurol. 2012, 67, 142-150. [CrossRef] 
73. Alonso-Canovas, A.; Katschnig, P.; Tucci, A.; Carecchio, M.; Wood, N.W.; Edwards, M.; Castrillo, J.C.M.; Burke, D.; Heales, S.; Dm, K.P.B. Atypical parkinsonism with apraxia and supranuclear gaze abnormalities in type 1 Gaucher disease. Expanding the spectrum: Case report and literature review. Mov. Disord. 2010, 25, 1506-1509. [CrossRef]

74. Pilotto, A.; Schulte, C.; Hauser, A.K.; Biskup, S.; Munz, M.; Brockmann, K.; Schaeffer, E.; Synofzik, M.; Maetzler, W.; Suenkel, U.; et al. GBA -associated parkinsonism and dementia: Beyond $\alpha$-synucleinopathies? Eur. J. Neurol. 2015, 23, 520-526. [CrossRef] [PubMed]

75. Rubio-Agusti, I.; Kojovic, M.; Edwards, M.J.; Murphy, E.; Chandrashekar, H.S.; Lachmann, R.H.; Dm, K.P.B. Atypical parkinsonism and cerebrotendinous xanthomatosis: Report of a family with corticobasal syndrome and a literature review. Mov. Disord. 2012, 27, 1769-1774. [CrossRef] [PubMed]

76. Van Der Zee, J.; Urwin, H.; Engelborghs, S.; Bruyland, M.; Vandenberghe, R.; Dermaut, B.; De Pooter, T.; Peeters, K.; Santens, P.; De Deyn, P.P.; et al. CHMP2B C-truncating mutations in frontotemporal lobar degeneration are associated with an aberrant endosomal phenotype in vitro. Hum. Mol. Genet. 2007, 17, 313-322. [CrossRef] [PubMed]

77. Chen-Plotkin, A.S.; Yuan, W.; Anderson, C.; Wood, E.M.; Hurtig, H.I.; Clark, C.M.; Miller, B.L.; Lee, V.M.-Y.; Trojanowski, J.Q.; Grossman, M.; et al. Corticobasal syndrome and primary progressive aphasia as manifestations of LRRK2 gene mutations. Neurol. 2007, 70, 521-527. [CrossRef] [PubMed]

78. Wszolek, Z.; Vieregge, P.; Uitti, R.; Gasser, T.; Yasuhara, O.; McGeer, P.; Berry, K.; Calne, D.; Vingerhoets, F.; Klein, C.; et al. German-Canadian family (family A) with parkinsonism, amyotrophy, and dementia-Longitudinal observations. Park. Relat. Disord. 1997, 3, 125-139. [CrossRef]

79. Rajput, A.; Dickson, D.W.; Robinson, C.A.; Ross, O.A.; Dächsel, J.C.; Lincoln, S.J.; Farrer, M.J. Parkinsonism, Lrrk2 G2019S, and tau neuropathology. Neurology 2006, 67, 1506-1508. [CrossRef] [PubMed]

80. Navarro, E.; De Andrés, C.; Guerrero, C.; Giménez-Roldán, S. Corticobasal Syndrome in a Family with Early-Onset Alzheimer's Disease Linked to a Presenilin-1 Gene Mutation. Mov. Disord. Clin. Pract. 2015, 2, 388-394. [CrossRef]

81. Abate, F.; Dati, G.; Ginevrino, M.; Valente, E.M.; Barone, P.; Picillo, M. APP -Related Corticobasal Syndrome: Expanding the List of Corticobasal Degeneration Look Alikes. Mov. Disord. Clin. Pract. 2020, 7, 849-851. [CrossRef]

82. Huey, E.D.; Ferrari, R.; Moreno, J.H.; Jensen, C.; Morris, C.M.; Potocnik, F.; Kalaria, R.N.; Tierney, M.; Wassermann, E.M.; Hardy, J.; et al. FUS and TDP43 genetic variability in FTD and CBS. Neurobiol. Aging 2012, 33, 1016.e9-1016.e17. [CrossRef]

83. Fekete, R.; Bainbridge, M.; Baizabal-Carvallo, J.F.; Rivera, A.; Miller, B.; Du, P.; Kholodovych, V.; Powell, S.; Ondo, W.; Kholodovich, V. Exome sequencing in familial corticobasal degeneration. Park. Relat. Disord. 2013, 19, 1049-1052. [CrossRef]

84. Höglinger, G.U. Is it Useful to Classify Progressive Supranuclear Palsy and Corticobasal Degeneration as Different Disorders? No. Mov. Disord. Clin. Pract. 2018, 5, 141-144. [CrossRef]

85. Clark, M.; Geschwind, D.H.; Fogel, B.L. The Neurogenetics of Atypical Parkinsonian Disorders. Semin. Neurol. 2014, 34, 217-224. [CrossRef]

86. Di Maria, E.; Tabaton, M.; Vigo, T.; Abbruzzese, G.; Bellone, E.; Donati, C.; Frasson, E.; Marchese, R.; Montagna, P.; Munoz, D.G.; et al. Corticobasal degeneration shares a common genetic background with progressive supranuclear palsy. Ann. Neurol. 2000, 47, 374-377. [CrossRef]

87. Myers, A.J.; Pittman, A.M.; Zhao, A.S.; Rohrer, K.; Kaleem, M.; Marlowe, L.; Hardy, J. The MAPT H1c risk haplotype is associated with increased expression of tau and es-pecially of 4 repeat containing transcripts. Neurobiol. Dis. 2007, 25, 561-570. [CrossRef]

88. Litvan, I.; Chism, A.; Litvan, J.; Cambon, A.; Hutton, M. H1/H1 genotype influences symptom severity in corticobasal syndrome. Mov. Disord. 2010, 25, 760-763. [CrossRef]

89. Houlden, H.; Baker, M.; Morris, H.; Macdonald, N.; Pickering-Brown, S.; Adamson, J.; Lees, A.; Rossor, M.; Quinn, N.; Kertesz, A.; et al. Corticobasal degeneration and progressive supranuclear palsy share a common tau haplotype. Neurology 2001, 56, 1702-1706. [CrossRef]

90. Kouri, N.; Ross, O.A.; Dombroski, B.; Younkin, C.S.; Serie, D.J.; Soto-Ortolaza, A.; Baker, M.; Finch, N.C.A.; Yoon, H.; Kim, J.; et al. Genome-wide association study of corticobasal degeneration identifies risk variants shared with progressive supranuclear palsy. Nat. Commun. 2015, 6, 7247. [CrossRef]

91. Yokoyama, J.S.; Karch, C.M.; Fan, C.C.; Bonham, L.W.; Kouri, N.; Ross, O.A.; Rademakers, R.; Kim, J.; Wang, Y.; Höglinger, G.U.; et al. Shared genetic risk between corticobasal degeneration, progressive supranuclear palsy, and frontotemporal dementia. Acta Neuropathol. 2017, 133, 825-837. [CrossRef]

92. Borroni, B.; Del Bo, R.; Goldwurm, S.; Archetti, S.; Bonvicini, C.; Agosti, C.; Bigni, B.; Papetti, A.; Ghezzi, S.; Sacilotto, G.; et al. VEGF Haplotypes are Associated with Increased Risk to Progressive Supranuclear Palsy and Corticobasal Syndrome. J. Alzheimers Dis. 2010, 21, 87-94. [CrossRef]

93. Moore, K.M.; Nicholas, J.; Grossman, M.; McMillan, C.T.; Irwin, D.J.; Massimo, L.; Van Deerlin, V.M.; Warren, J.D.; Fox, N.C.; Rossor, M.N.; et al. Age at symptom onset and death and disease duration in genetic frontotemporal dementia: An international retrospective cohort study. Lancet Neurol. 2020, 19, 145-156. [CrossRef]

94. Lee, D.-W.; Eum, S.-W.; Moon, C.O.; Ma, H.-I.; Kim, Y.J. Corticobasal syndrome associated with antiphospholipid syndrome without cerebral infarction. Neurology 2014, 82, 730-731. [CrossRef] [PubMed]

95. Almeida, M.R.; Baldeiras, I.; Ribeiro, M.H.; Santiago, B.; Machado, C.; Massano, J.; Guimarães, J.; Oliveira, C.R.; Santana, I. Progranulin Peripheral Levels as a Screening Tool for the Identification of Subjects with Progranulin Mutations in a Portuguese Cohort. Neurodegener. Dis. 2013, 13, 214-223. [CrossRef] [PubMed] 